\title{
Therapeutic Effects of Glycine in Isovaleric Acidemia
}

\author{
INGEBORG KRIEGER ${ }^{(27)}$ AND KAY TANAKA \\ Department of Pediatrics, Wayne State University School of Medicine and The Metabolic Service, Children's \\ Hospital of Michigan, Detroit, Michigan, and The Department of Human Genetics, Yale University School of \\ Medicine, New Haven, Connecticut, USA
}

\section{Extract}

The effect of glycine administration on acute leucine loading ( 125 $\mathrm{mg} / \mathrm{kg}$ ) was tested in a patient with isovaleric acidemia. Serum isovaleric acid at $13 / 4 \mathrm{hr}$ after the leucine loading alone was elevated to $5.60 \mathrm{mg} / 100 \mathrm{ml}$ and urinary isovalerylglycine excretion was 9.90 $\mathrm{mg} / \mathrm{mg}$ creatinine $/ 24 \mathrm{hr}$. When the same amount of leucine was given with glycine $(250 \mathrm{mg} / \mathrm{kg})$ serum isovaleric acid was only 0.93 $\mathrm{mg} / 100 \mathrm{ml}$. Unfortunately, urine was collected for only $12 \mathrm{hr}$ after the leucine-glycine loading. However, the amount of urinary isovalerylglycine was $26.2 \mathrm{mg} / \mathrm{mg}$ creatinine in this period. In the following experiments in which a meal containing $80 \mathrm{mg}$ leucine $/ \mathrm{kg}$ was given, serum isovaleric acid was elevated to 1.14 and 1.01 $\mathrm{mg} / 100 \mathrm{ml}$ at $3 \mathrm{hr}$ and $6 \mathrm{hr}$ after the loading, respectively. How-ever, serum isovaleric acid was only 0.53 and $0.79 \mathrm{mg} / 100 \mathrm{ml}$ at 3 and 6 $\mathrm{hr}$, respectively, when the identical mean was given with $2 \mathrm{~g}$ glycine.

The effect of long term glycine administration $(250 \mathrm{mg} / \mathrm{kg} / 24 \mathrm{hr}$ ) was also tested. It did not prevent two ketotic episodes which were caused by infections. However, the duration of clinical symptoms such as vomiting and a large anion gap in the acute episodes were much shorter with rectal glycine administration. The patient's linear growth and weight gain during glycine administration was much better than that in the pretreatment period.

\section{Speculation}

In isovaleric acidemia, isovaleryl-CoA is not oxidized because of an inborn deficiency of isovaleryl-CoA dehydrogenase activity. The leucine loading tests and clinical response to oral glycine in this patient suggest that exogenously administered glycine enhanced the conjugation of glycine with isovaleryl-CoA, thus preventing accumulation of free isovaleric acid, a toxic substance. With glycine administration, mitochondrial glycine concentration seems to be elevated to a level at which faster reaction velocity of glycine- $N$ acylation of isovaleryl-CoA is attained. Thus, glycine administration appears to be an effective therapeutic method in the management of acute ketoacidotic episodes in this disease. However, chronic administration failed to prevent ketoacidotic episodes which were induced by infections.

In the treatment of inborn errors of amino acid metabolism, reduction of toxic metabolites, which accumulate because of enzyme deficiency, may be accomplished by restriction of the intake of protein or of the precursor amino acid. This approach, however, is not effective when catabolic processes increase the endogenous amino acid load. Such instances are observed in patients with isovaleric acidemia (24), propionic acidemia, and methylmalonic acidemia as severe ketoacidotic episodes which often accompany systemic infections. Moreover, the necessary degree of protein restriction may limit growth and development. Reduction of the toxic metabolite may therefore be best accomplished by enhancement of detoxification if such a mechanism exists. Treatment of nonketotic hyperglycinemia with sodium benzoate is an example (12). Unfortunately, few metabolic diseases can be treated successfully in this fashion.
Isovaleric acidemia is an inherited defect of leucine metabolism. This disease is due to an enzyme defect at the level of isovaleryl-CoA dehydrogenase $(22,24)$. Isovaleryl-CoA cannot be oxidized further but usually is effectively conjugated with glycine by glycine $N$-acylase and excreted as urinary isovalerylglycine (23). However, when the leucine load exceeds the capacity of the glycine conjugation system, excessive isovaleryl-CoA is hydrolyzed, resulting in an accumulation of isovaleric acid and severe ketoacidosis $(22,23)$. Patients with this disease have been treated with infusion of glucose and by correction of acidosis when ketoacidotic episodes occur $(5,15)$. A low protein diet has also been tried (14). However, no specific therapy for this disease has been known.

One possible approach to the treatment of isovaleric acidemia would be to raise the intracellular concentration of the other substrate of glycine $N$-acylase, namely glycine, to enhance the detoxification of isovaleryl-CoA. We report here our experience in treating a patient with isovaleric acidemia by glycine administration which resulted in improvement through enhancement of the detoxification mechanism. In acute loading tests with leucine. serum isovaleric acid concentration remained much lower when glycine was simultaneously administered, whereas urinary isovalerylglycine excretion increased significantly. The clinical and biochemical effects of long term glycine treatment, which lasted 6 months, are also described.

\section{CASE REPORT}

\section{CLINICAL FINDINGS}

The patient is a Negro female who was born at term, September 1968 , with a birth weight of $2,280 \mathrm{~g}$. The mother is microcephalic and mildly retarded, but otherwise in good health. The patient had a total of 12 major attacks of ketoacidosis in 5.5 years. The first was at 2 weeks of age when she became lethargic and refused to suck. During a similar episode at 2 months she became unresponsive and lost all of her hair. A bone survey showed osseous demineralization. Insufficient weight gain, slow development, and evidence of organic brain damage were noted at 4.5 months, at which time diffuse disorganization was noted on the electroencepalogram. There were four episodes of vomiting during the next year and two during the year after. Her parents attributed some episodes to an excessive intake of fruit. Other attacks, when she was older, were attributed to overeating of tuna and turkey. An offensive odor of sweat was noticed during several of the early admissions. Premature closure of the saggital suture was noted at 2 years. Between 2.5 and 6 years of age no attacks occurred. In the fall of 1973, there was a recurrence of ketoacidosis which led to the diagnosis and investigations described in this report. She was admitted to the Emergency Room of the Children's Hospital of Michigan in a severely dehydrated condition because of repeated vomiting for 2 days. She was moribund with cloudy corneas, slow pupillary reaction to light, and Kussmaul respiration. Heart rate was $150 / \mathrm{min}$. Her growth was retarded (height, $100 \mathrm{~cm}$ : weight. $12.3 \mathrm{~kg}$ ). She was microcephalic (head circumference $45 \mathrm{~cm}$ ). A Stanford-Binet intelligence test at 5 years of age showed a score of 24. 


\section{LABORATORY FINDINGS}

Serum electrolyte determinations indicated the presence of a large anion gap (32-44 mEq/liter) during four of five ketotic attacks. Carbon dioxide content ranged from 13.0 to $20.8 \mathrm{mEq} / \mathrm{li}$ ter, and the $\mathrm{pH}$ was 7.18 and 7.29. Urines were generally strongly positive for acetone. Six of the ketotic episodes were associated with leukopenia, which ranged from 1,400 to $3,600 / \mathrm{mm}^{3}$. During these episodes nonsegmented polymorphonuclear cells (mean: $33 \%$ ) predominated over segmented cells (mean: $22 \%$ ). Platelet counts were normal. Plasma amino acids were normal, except for glycine, which was slightly elevated on one of five tests as discussed below. Urine amino acids were also normal. Urinary amino acid values after acid hydrolysis were similar to two normal control subjects, including a 10 -fold increase of glutamate over values without acid hydrolysis. This increase is apparently due to hydrolysis of phenylacetylglutamine (20). Urinary excretion of methylmalonic acid was normal. Propionic acidemia was ruled out through determination of leukocyte propionyl-CoA carboxylase (11). Because intermittent ketoacidotic episodes accompanied with the characteristic offensive odor were suggestive of iosvaleric acidemia, a leucine loading test was performed as described in the following section. The results from this test led to the diagnosis of isovaleric acidemia as shown in Table 1 . The basal metabolic rate (BMR) was $87.6 \mathrm{kcal} / 24 \mathrm{hr} / \mathrm{kg}$ at 6 months of age. An elevation of this degree can be attributed to a change in body composition due to malnutrition, mainly the loss of fat which has relatively low metabolic activity. However, underweight infants have a normal BMR per unit of body weight predicted from height, and when the BMR of this patient was expressed on this basis it was still elevated $(60.5 \mathrm{kcal} / 24 \mathrm{hr} / \mathrm{kg}$ predicted weight vs. normal $53.09 \pm 2.62 \mathrm{SD})$ (13). Plasma thyroxine was normal. Blood-urea-nitrogen and serum creatinine were repeatedly normal. Since 14 months of age urinalyses consistently showed heavy proteinuria both during and between attacks. Quantitative determinations showed $518 \mathrm{mg}$ protein and 135 and $250 \mathrm{mg} \alpha$-amino nitrogen in 24-hr urine specimens collected at 25 months of age. Fasting blood sugar at 5.5 years was $62 \mathrm{mg} / 100 \mathrm{ml}$ and cholesterol, $81 \mathrm{mg} / 100 \mathrm{ml}$.

Oral loading tests were done with l-isoleucine $(150 \mathrm{mg} / \mathrm{kg})$, 1-threonine $(125 \mathrm{mg} / \mathrm{kg})$, l-valine $(250 \mathrm{mg} / \mathrm{kg})$, and l-leucine $(125$ $\mathrm{mg} / \mathrm{kg}$ ). The details of the leucine loading test are described under Results. All other amino acids were well tolerated.

\section{METHODS AND MATERIALS}

Serum and urine samples were stored frozen until analysis. Serum isovaleric acid was measured by the method described pre-

Table 1. Effect of glycine on acute leucine loading test ${ }^{1}$

\begin{tabular}{|c|c|c|c|}
\hline \multirow[b]{2}{*}{ Subjects } & \multirow{2}{*}{$\begin{array}{c}\text { Serum } \\
\text { isovaieric } \\
\text { acid, } \\
\mathrm{mg} / 100 \mathrm{ml}\end{array}$} & \multicolumn{2}{|c|}{ Urine, $\mathrm{mg} / \mathrm{mg}$ creatinine } \\
\hline & & $\begin{array}{l}\text { Isovaleric } \\
\text { acid }\end{array}$ & $\begin{array}{l}\text { Isovaleryl- } \\
\text { glycine }\end{array}$ \\
\hline $\begin{array}{l}\text { Control } \\
\text { Patient }\end{array}$ & $0.05(24)$ & $<0.002(22)^{2}$ & $<0.02(23)^{2}$ \\
\hline Baseline & 0.77 & 0.013 & 6.30 \\
\hline Leucine $(125 \mathrm{mg} / \mathrm{kg})$ & $5.60^{3}$ & 0.023 & 9.90 \\
\hline $\begin{array}{l}\text { Leucine }(125 \mathrm{mg} / \mathrm{kg}) \\
\quad+\text { glycine }(250 \mathrm{mg} / \mathrm{kg})\end{array}$ & $0.93^{3}$ & 4 & $26.20^{5}$ \\
\hline
\end{tabular}

${ }^{1}$ Leucine and glycine were given as aqueous solutions; glycine was given 15 min after leucine administration.

${ }^{2}$ Calculated from the referenced data on the assumption that 3 - to 5-year-old normal children excrete $100-300 \mathrm{mg}$ creatinine/24 $\mathrm{hr}$ (3).

${ }^{3}$ Blood samples $\mathrm{l} 3 / 4 \mathrm{hr}$ after leucine administration. Urine samples were collected for $24 \mathrm{hr}$ after leucine loading except for that described in footnote 5 .

${ }^{4}$ Not measured.

s This urine sample was collected for only $12 \mathrm{hr}$.

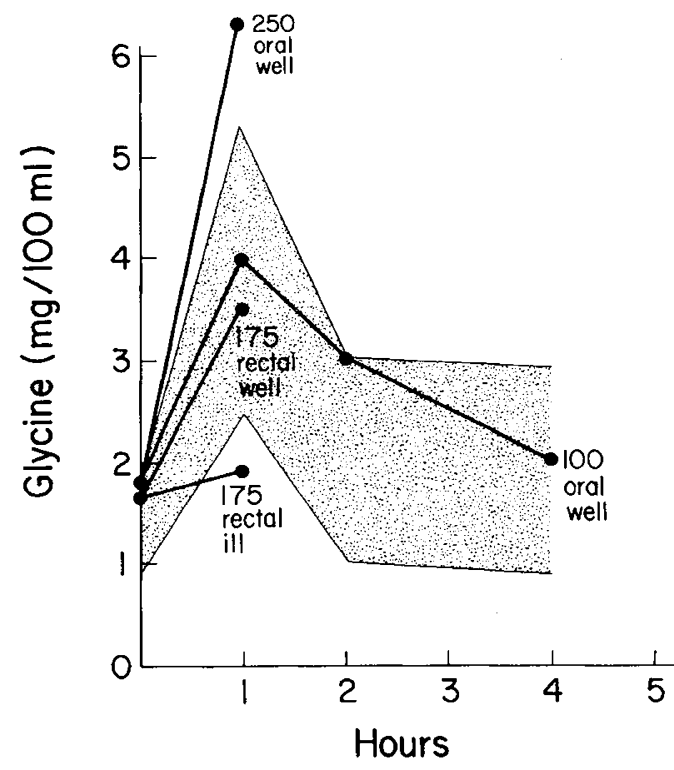

Fig. 1. Plasma glycine after oral or rectal administration of glycine in the specified amounts: 100,175 , or $250 \mathrm{mg} / \mathrm{kg}$. Shaded area represents range of values observed in three normal infants (19) given $200 \mathrm{mg} / \mathrm{kg}$ orally.

viously (24). Urinary isovalerylglycine was determined according to the method of Tanaka and Isselbacher (23) with slight modifications. Plasma amino acids were analyzed by column chromatography with the use of a Technicon amino acid analyzer after resin deproteinization. For oral as well as rectal loading tests, amino acids were dissolved in $60 \mathrm{ml}$ water.

\section{RESULTS}

\section{EFFECT OF GLYCINE ADMINISTRATION ON LEUCINE LOADING TEST}

In an attempt to find the proper dosage and the patient's response, glycine was given first alone in an amount of $250 \mathrm{mg} / \mathrm{kg}$. The plasma glycine level at $1 \mathrm{hr}$ was $6.12 \mathrm{mg} / 100 \mathrm{ml}$ (Fig. 1). Following a dose of $100 \mathrm{mg}$ glycine $/ \mathrm{kg}$ with a meal, plasma glycine was $3.95 \mathrm{mg} / 100 \mathrm{ml}$. This value and the values obtained after 2 and $4 \mathrm{hr}$ were similar to those of normal control subjects receiving a roughly comparable amount of glycine (19). A glycine dose of $175 \mathrm{mg} / \mathrm{kg}$ was then given rectally, once when the patient was well, and once during ketoacidosis. When the patient was well, plasma glycine rose to $3.54 \mathrm{mg} / 100 \mathrm{ml}$ within $1 \mathrm{hr}$. In contrast, during ketoacidosis, no increase was observed in the plasma glycine level (Fig. 1). Since the amount of isovaleryl-CoA is assumed to be higher during ketoacidosis, one explanation for the low plasma glycine level would be the utilization of exogenous glycine for conjugation.

Three types of leucine loading tests were done. Each set of loading tests was performed with and without glycine administration. The first set of loading tests was done by oral administration of leucine solution in the amount of $125 \mathrm{mg} / \mathrm{kg}$ body weight. The patient excreted $6.30 \mathrm{mg}$ isovalerylglycine and $0.013 \mathrm{mg}$ isovaleric acid/mg creatinine, respectively, during the $24 \mathrm{hr}$ preceding the loading tests. When leucine was given, vomiting started $13 / 4$ hours after the loading and continued for $8 \mathrm{hr}$. Serum isovaleric acid rose from 0.77 before loading to $5.60 \mathrm{mg} / 100 \mathrm{ml}$ in $13 / 4 \mathrm{hr}$. After the leucine loading, urinary excretion of isovalerylglycine and isovaleric acid during the $24 \mathrm{hr}$ increased to 9.90 and $0.023 \mathrm{mg} / \mathrm{mg}$ creatinine, respectively (Table 1). When the same amount of leucine was given with $250 \mathrm{mg}$ glycine $/ \mathrm{kg}$, vomiting did not occur. The serum sample which was taken before the leucine-glycine load was lost during analysis. However, serum isovaleric acid was elevated only to $0.93 \mathrm{mg} / 100 \mathrm{ml}$ at $13 / 4 \mathrm{hr}$. It is much lower than the 
value observed after the leucine loading alone and not significantly different from the baseline value in the previous loading test. Unfortunately, urine was collected for only $12 \mathrm{hr}$ after the leucineglycine loading. The amount of urinary isovalerylglycine was 26.20 $\mathrm{mg} / \mathrm{mg}$ creatinine in this period (Table 1). This value is significantly higher than the values observed with leucine loading alone even when we assume that only the basal amount of isovalerylglycine was excreted in the next $12 \mathrm{hr}$ (such a mean value for $24 \mathrm{hr}$ would be $16.3 \mathrm{mg} / \mathrm{mg}$ creatinine).

To confirm the beneficial effects of glycine on leucine loading, two more sets of experiments were performed. In the second set of experiments, the patient was given three meals a day for 5 days, each containing about $400 \mathrm{mg}$ leucine (total: $100 \mathrm{mg} / \mathrm{kg} / 24 \mathrm{hr}$ ). Each mean was followed by $1 \mathrm{~g}$ glycine within $15 \mathrm{~min}$. During this 5-day period the urine was pooled. Total urinary isovalerylglycine excretion in the 5-day period was $9,210 \mathrm{mg}$. In the following 5-day period, she was given the same diet without glycine. In this period she excreted $6,910 \mathrm{mg}$ isovalerylglycine (Table 2). However, when urinary isovalerylglycine excretion in these two 5-day periods was expressed in milligrams per $\mathrm{mg}$ creatinine, there was no significant difference. Had the leucine load been large enough to cause ketoacidosis, we might have seen a greater difference in the excretion of isovalerylglycine during the two periods.

In the third experiment a protein meal which contained $80 \mathrm{mg}$ leucine $/ \mathrm{kg}$ body weight was given with or without glycine administration. The serum isovaleric acid levels after the meal without glycine were 1.14 and $1.01 \mathrm{mg} / 100 \mathrm{ml}$ at $3 \mathrm{hr}$ and at $6 \mathrm{hr}$, respectively. However, when $2 \mathrm{~g}$ glycine were given as an aqueous solution $15 \mathrm{~min}$ after an identical meal, serum isovaleric acid levels were 0.53 and $0.79 \mathrm{mg} / 100 \mathrm{ml}$ at 3 and $6 \mathrm{hr}$, respectively. These values are significantly lower than the values observed when the same meal was given without glycine (Table 3 ).

\section{CLINICAL OBSERVATIONS ON EFFECT OF GLYCINE ADMINISTRATION DURING KETOTIC EPISODES AND IN REMISSION}

After demonstrating the beneficial effect of glycine through leucine loading tests the patient had another severe attack in 1974 , again associated with loss of hair. Informed consent was obtained from the mother, and the child was placed on $250 \mathrm{mg}$ glycine/ $\mathrm{kg} / 24 \mathrm{hr}$ for 6 months. The glycine was administered in three doses after meals. The daily protein allowance of $1.5 \mathrm{~g} / \mathrm{kg}$ was also divided into three meals with equal leucine content (total: 125 $\mathrm{mg} / \mathrm{kg} / 24 \mathrm{hr}$ ). Thus, the daily intake of leucine and glycine was planned to be similar to the amounts given in the loading experiments. However, repeated $24-\mathrm{hr}$ dietary recall did not indicate a persistent change in food intake. Reliable assessment of the average food intake over a long period of time during chronic glycine administration was not possible because the patient was not in the hospital during this period.

In the 6 months of glycine treatment, linear growth of $5.8 \mathrm{~cm}$ exceeded that of the preceding 6 months by $50 \%$. Weight gain during the same period was $2.05 \mathrm{~kg}$ in contrast to $0.80 \mathrm{~kg}$ gained in 6 months without glycine. It was noted during chronic glycine

Table 2. Effect of glycine on urinary excretion of isovalerylglycine in a 5-day period ${ }^{1}$ on a diet with fixed leucine content (100 $m g / k g /$ day)

\begin{tabular}{lcc}
\hline & Urinary isovalerylglycine \\
\hline & $\mathrm{mg} / 5$ days & $\begin{array}{c}\mathrm{mg} / \mathrm{mg} \\
\text { creatinine }\end{array}$ \\
\hline No glycine & 6,910 & 8.46 \\
With glycine $(3 \mathrm{~g} / 24 \mathrm{hr})$ & 9,210 & 8.76 \\
\hline
\end{tabular}

${ }^{1}$ These experiments were done while the patient was in good health.

${ }^{2}$ In pooled 5-day collection.
Table 3. Effect of glycine on serum isovaleric acid after a meal containing $80 \mathrm{mg}$ leucine $/ \mathrm{kg}$ body weight

\begin{tabular}{ccc}
\hline \multirow{2}{*}{$\begin{array}{c}\text { Time after } \\
\text { meal, } \mathrm{hr}\end{array}$} & \multicolumn{2}{c}{ Serum isovaleric acid, $\mathrm{mg} / \mathrm{l} 00 \mathrm{ml}$} \\
\cline { 2 - 3 } & ${\text { With glycine }(2 \mathrm{~g})^{1}}^{1}$ & No glycine \\
\hline 3 & 0.53 & 1.14 \\
6 & 0.79 & 1.01 \\
\hline
\end{tabular}

${ }^{1}$ Glycine was given in aqueous solution 15 min after the meal.

therapy that the child occasionally craved meat. In March 1974, glycine was discontinued for 2 days when the patient refused foods because of a sore throat. This infection induced a ketoacidotic attack. Instructions were then changed to provide for three glycine doses per day, to be given even if meals were refused. Six months later she developed a mild cold followed by diarrhea. Although she appeared well at bedtime, she awoke at 7 o'clock the next morning, after a 14-hr fast, and vomited 14 times until noon. Extra doses of oral glycine, given at the onset of vomiting, were not retained. She was therefore admitted and given $200 \mathrm{mg} / \mathrm{kg}$ glycine rectally every $6 \mathrm{hr}$ as well as intravenous glucose $(1 \mathrm{~g} / \mathrm{kg})$ in normal saline with insulin ( $1 \mathrm{U} / 5 \mathrm{~g}$ glucose). Whereas previous attacks lasted for at least 6 days despite intravenous fluid therapy for ketoacidosis, on this occasion vomiting stopped in the afternoon of the day of admission. She retained fluids during the night and ate a full breakfast the next morning. An anion gap of 32-44 mEq/liter was observed in the beginning but improved to $13 \mathrm{mEq} /$ liter within 36 hr of treatment with glycine. In the last attack, which occurred 1.5 months later, vomiting subsided promptly with rectal glycine and intravenous fluid therapy but without insulin. An anion gap of 30 $\mathrm{mEq} /$ liter was observed initially in this episode but was reduced to $11 \mathrm{mEq} /$ liter within $24 \mathrm{hr}$.

Plasma amino acid levels before and during glycine therapy are summarized in Table 4. Only amino acids which showed changes are listed. Before glycine therapy, plasma glycine levels observed during attacks tended to be lower than the values during remission. In one of two determinations which were conducted during remission, plasma glycine was slightly elevated. Glycine loading induced a rise of alanine and glutamate. Consequently, glycine-alanine ratios were near unity, except for two attacks of ketoacidosis, when the level of glycine was lower than that of alanine.

\section{DISCUSSION}

In 1967 Tanaka and Isselbacher (23) identified a large amount of isovalerylglycine in urine of patients with isovaleric acidemia. They have shown that conjugation of isovaleryl-CoA with glycine plays an important role in its detoxification in these patients. Since then treatment of patients with isovaleric acidemia by glycine administration appeared to be promising. But such an attempt has never been reported until now. In other organic acidemias such as propionic (10) and methylmalonic acidemia (17) and $\alpha$ methylacetoacetyl-CoA $\beta$-ketothiolase deficiency (8), severe hyperglycinemia is often observed. In contrast, the plasma glycine level is usually not elevated in patients with isovaleric acidemia, with the exception of two patients $(1,6)$ who had a slight to moderate elevation of plasma glycine. This difference in plasma glycine concentration in these organic acidemias appears to be due to at least two factors. First, in propionic acidemia (2) and $\alpha$-methylacetoacetyl-CoA $\beta$-ketothiolase deficiency (8), cleavage of $\left[1-{ }^{14} \mathrm{C}\right] \mathrm{glycine}$ to ${ }^{14} \mathrm{CO}_{2}$ was inhibited but was normal in patients with isovaleric acidemia (1). The second factor is the difference of affinity of glycine $N$-acylase for various acyl-CoA's. Propionyl-CoA and methylmalonyl-CoA are poor substrates for this enzyme (4). Therefore, no glycine conjugates of methylmalonate or propionate, or very few (16), are detected in these diseases. Isovaleryl-CoA, on the other hand, is a very good substrate for this 
Table 4. Levels of plasma amino acids ${ }^{1}$ before and after glycine administration

\begin{tabular}{|c|c|c|c|c|c|c|c|c|c|c|c|}
\hline \multirow{5}{*}{$\begin{array}{l}\text { Amino } \\
\text { acids }\end{array}$} & \multicolumn{11}{|c|}{ Plasma amino acid levels, $\mathrm{mg} / 100 \mathrm{ml}$} \\
\hline & \multirow{2}{*}{\multicolumn{2}{|c|}{ Control subjects ${ }^{2}$}} & \multicolumn{9}{|c|}{ Patient } \\
\hline & & & \multicolumn{2}{|c|}{ Well } & \multicolumn{3}{|c|}{ Ketoacidosis } & \multicolumn{2}{|c|}{ Well (1974) } & \multicolumn{2}{|c|}{ Ketoacidosis (1974) } \\
\hline & \multirow{2}{*}{$\begin{array}{c}\text { Before } \\
1974\end{array}$} & \multirow{2}{*}{$\begin{array}{l}\text { After } \\
1974\end{array}$} & \multirow[b]{2}{*}{1970} & \multirow[b]{2}{*}{1974} & \multirow[b]{2}{*}{1970} & \multirow[b]{2}{*}{1971} & \multirow[b]{2}{*}{1974} & \multicolumn{2}{|c|}{ Oral glycine load ${ }^{3}$} & \multicolumn{2}{|c|}{ Rectal glycine load ${ }^{3}$} \\
\hline & & & & & & & & $250 \mathrm{mg} / \mathrm{kg}$ & $100 \mathrm{mg} / \mathrm{kg}^{4}$ & $175 \mathrm{mg} / \mathrm{kg}^{4}$ & $175 \mathrm{mg} / \mathrm{kg}^{4}$ \\
\hline Threonine $^{5}$ & 1.54 & 2.14 & 1.03 & $1.10^{5}$ & 1.18 & 0.31 & $0.58^{5}$ & $0.51^{5}$ & $2.57^{5}$ & $\operatorname{tr}^{5}$ & $4.89^{5}$ \\
\hline Serine & 1.96 & 1.79 & 1.36 & 1.41 & 1.28 & 0.36 & 0.53 & 2.09 & 2.42 & 2.14 & 1.07 \\
\hline Glutamate & 3.67 & 3.63 & 1.48 & 3.49 & 1.42 & 1.37 & 0.73 & 3.94 & 2.94 & 3.68 & 4.98 \\
\hline Glycine & 1.98 & 2.33 & 1.98 & 2.10 & 1.55 & 0.46 & 1.73 & 6.12 & 4.44 & 3.51 & 1.57 \\
\hline Alanine & 3.17 & 3.65 & 2.15 & 2.14 & 1.53 & 0.84 & 1.47 & 5.63 & 5.92 & 3.55 & 2.02 \\
\hline Valine & 2.56 & 3.28 & 1.13 & 1.12 & 1.66 & 1.03 & 3.66 & 2.41 & 2.64 & 2.58 & 3.05 \\
\hline Isoleucine & 0.83 & 1.71 & 0.42 & 0.63 & 0.57 & 0.29 & 1.14 & 1.09 & 1.12 & 0.90 & 1.93 \\
\hline Leucine & 1.68 & 2.89 & 1.00 & 1.28 & 1.01 & 0.51 & 1.95 & 1.98 & 1.90 & 1.87 & 2.88 \\
\hline
\end{tabular}

${ }^{1}$ Only amino acids which showed changes are listed. Levels of other amino acids remained within normal range.

${ }^{2}$ Upper limit of normal. Two different control values for each amino acid is due to a change of instrumentation.

${ }^{3}$ Blood samples were taken one hour after a single load of specified amounts. Loading tests conducted while the patient was well were started after a 12-hr fast.

${ }^{4}$ These tests were done while the patient was on glycine therapy. The patient was receiving glycine $(250 \mathrm{mg} / \mathrm{kg} / 24 \mathrm{hr}) \mathrm{during}$ the 6 -month period.

${ }^{5}$ Includes glutamine and asparagine.

enzyme (4), and glycine is very well utilized for the conjugation of isovaleryl-CoA in isovaleric acidemia (1). Thus, a large amount of isovalerylglycine is always excreted in urine of patients with isovaleric acidemia $(22,23)$. In the present case and also in the patient reported previously (24), plasma glycine levels seem to be lower during ketoacidotic attacks than in remission. These findings are indicative of an inadequate supply of glycine to handle increased amounts of isovaleryl-CoA produced in ketoacidotic attacks. We therefore considered it possible to enhance glycine conjugation of isovaleryl-CoA by raising the glycine concentration in tissues by exogenous administration.

The effect of exogenous glycine administration on acute leucine loading tests were therefore investigated. A marked elevation of serum isovaleric acid has been observed after leucine loading in the two patients originally reported by Tanaka et al. (24). In the present case a similar elevation of serum isovaleric acid was observed when leucine alone was given. However, when leucine was given with glycine the elevation of serum isovaleric acid was minimal. Vomiting occurred when leucine alone was given but it did not occur when leucine was given with glycine. More significantly, the amount of urinary isovalerylglycine was much larger after joint administration of leucine and glycine than after administration of leucine alone. A similar effect was observed when leucine was administered in the form of protein diet. Thus we are able to show that an exogenous supply of glycine is effective in enhancing glycine conjugation of an excessive amount of isovaleryl-CoA produced by leucine loading. The conjugation prevented the accumulation of free isovaleric acid, a toxic substance.

Our observations in vivo on this patient seem to be in accordance with the enzymologic data on bovine glycine $N$-acylase by Bartlett and Gompertz (4). They observed a very high $\mathrm{V}_{\max }$ $(12.3 \mu \mathrm{mol} / \mathrm{min} / \mathrm{mg}$ protein $)$ and a relatively high $\mathrm{K}_{\mathrm{m}}(0.19 \mathrm{mM})$ for isovaleryl-CoA. The $\mathrm{V}_{\max }$ and $\mathrm{K}_{\mathrm{m}}$ values are $4.4 \mu \mathrm{mol} /$ $\mathrm{min} / \mathrm{mg}$ protein and $0.009 \mathrm{mM}$ for benzoyl-CoA. If we assume that human glycine $N$-acylase has similar characteristics, then isovaleryl-CoA has a very high reactivity with glycine when concentration of isovaleryl-CoA is elevated in tissues, as in the case of patients with isovaleric acidemia. Furthermore, with the bovine enzyme, the $\mathrm{K}_{\mathrm{m}}$ value for glycine is high $(3.3 \mathrm{mM})$. Since glycine concentration in human liver tissue $(74.4 \pm 32.2 \mu \mathrm{g} / \mathrm{g})$ is low (21), acylation of glycine with isovaleryl-CoA may be greatly enhanced if glycine concentration in liver tissue is raised. Although they must be confirmed by investigation of human glycine $N$-acylase in vitro, our assumptions seem to be supported by the observation of Ando

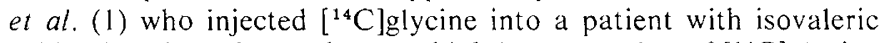
acidemia. They observed a very high incorporation of $\left[{ }^{14} \mathrm{C}\right]$ glycine into urinary isovalerylglycine, whereas the labeling of hippurate was almost not detectable in their study. Hippurate is the glycine conjugate of benzoic acid which arises from diet as well as from metabolism of phenylalnine. It is a normal constituent in human urine and is highly labeled with $\left[{ }^{14} \mathrm{C}\right]$ glycine when $\left[{ }^{14} \mathrm{C}\right]$ glycine is injected to a control. These data indicated that exogenous glycine is utilized much more extensively for the synthesis of isovalerylglycine than for that of hippurate in the patient with isovaleric acidemia.

After we confirmed the effectiveness of glycine administration in acute leucine loading tests, the patient was placed on long term glycine administration in the hope of preventing a recurrence of ketoacidotic attacks. Long term treatment with glycine was considered safe because glycine was widely used in large amounts $(7.5-25 \mathrm{~g} / 24 \mathrm{hr})$ in the past in the treatment of patients with muscular dystrophy apparently without any significant side effects (7). It has also been shown that the metabolism of glycine to $\mathrm{CO}_{2}$ was normal in a patient with isovaleric acidemia (1). Our patient ate more meat and grew more in weight and height in the 6 months of glycine administration than the preceding 6 months. However, it must be pointed out that during the time the patient was receiving chronic glycine therapy it was difficult to control her diet. Glycine administration did not prevent two ketotic attacks which occurred when she developed upper respiratory infections. However, the duration of these attacks was much shorter when ordinary intravenous therapy was supplemented with rectal glycine administration. Thus, although the therapeutic effect of glycine administration in acute ketotic attacks appears to be ascertained, chronic glycine therapy must be tested carefully and evaluated in the future, especially in view of the moderate elevation of alanine and glutamate observed in the course of the treatment.

Since glycine conjugation with isovaleryl-CoA is instrumental in preventing isovaleric acid accumulation during remission, it is advisable to restrict substances which compete for glycine conjugation, such as benzoic and salicylic acids. Benzoic acid is derived from fruits and increased intake of fruits seemed to have played a role in precipitating attacks during infancy in this patient. Salicylate ingestion may have been a contributing factor in the 
case described by Ando et al. (1). In ketoacidotic episodes, correction of acidosis is important. Schachter et al. (18) demonstrated decreased reaction velocities for glycine conjugation at low $\mathrm{pH}$ levels with bovein glycine $N$-acylase. Thus, acidosis which develops from other causes may set in motion a vicious cycle in which glycine conjugation decreases because of the low $\mathrm{pH}$ causing accumulation of isovaleric acid and further lowering of the $\mathrm{pH}$. Consequently, prevention and prompt correction of acidosis is crucial in the management of acute ketoacidotic episodes.

Two peculiar findings were observed in this patient, although they are unrelated to glycine therapy. One is the elevation of BMR. Since there was no clinical sign of hyperthyroidism and serum thyroxin was normal, the elevation of BMR is not due to hyperthyroidism. It is interesting to note that short chain fatty acids including isovaleric acid are uncouplers of oxidative phosphorylation (9). Therefore, it is possible that the observed elevation of BMR is due to the effect of elevated isovaleric acid in tissues. The other observation is the loss of hair which occurred twice during ketoacidotic episodes. Its mechanisms are currently unknown.

\section{SUMMARY}

Leucine, which is not normally metabolized in isovaleric acidemia, was given to a patient with this disorder as a single amino acid load and in the form of a protein meal, first alone and then in conjunction with oral glycine. It was shown that glycine has a detoxifying effect because it decreased the level of serum isovaleric acid and caused an increased urinary excretion of the nontoxic conjugation product, isovalerylglycine. Long term glycine administration was well tolerated but did not prevent ketotic episodes induced by infections. During several attacks rectal glycine was effective in shortening the duration of the ketosis.

\section{REFERENCES AND NOTES}

1. Ando, T., Klingberg, W. G., Ward, A. N., Rasmussen, K., and Nyhan, W. L.: Isovaleric acidemia presenting with altered metabolism of glycine. Pediat. Res., 5: 478 (1971).

2. Ando, T., Nyhan, W. L., Connor, J. D., Rasmussen, K., Donnell, G., Barnes, N., Cottom, D., and Hull, D.: The oxidation of glycine and propionic acid in propionic acidemia with ketotic hyperglycinemia. Pediat. Res., 6:576 (1972).

3. Appelgarth, D. A., Harwick, D. F., and Moss, P. M.: Creatinine excretion in children and the usefulness of creatinine equivalents in amino acid chromatography. Clin. Chim. Acta, 22: 131 (1968).

4. Bartlett, K., and Gompertz, D.: The specificity of glycine- $N$-acylase and acylglycine excretion in the organic acidemias. Biochem. Med., 10:15 (1974).

5. Budd, M. A., Tanaka, K., Holmes, L. B., Efron, M. L., Crawford, J. D., and
Isselbacher, K. J.: Isovaleric acidemia: Clinical features of new genetic defect of leucine metabolism. N. Engl. J. Med., 277: 321 (1967).

6. Guibaud, P., Divry, P., Dubois, Y., Collombel, C., and Larbre, F.: Une observation d'acidemie isovalerique. Arch. Franc. Pediat., 30: 633 (1973).

7. Harris, M. M., and Brand, E.: Metabolic and therapeutic studies in the myopathies. J. Amer. Med. Ass., 101: 1048 (1933).

8. Hillman, R. E., Sower, L. H., and Cohen, J. L.: Inhibition of glycine oxidation in cultured fibroblasts by isoleucine. Pediat. Res., 7: 945 (1973).

9. Hird, F. J. R., and Weideman, M. J.: Oxidative phosphorylation accompanying oxidation of short chain fatty acids by rat liver mitochondria. Biochem. J., 98: 378 (1966).

10. Hsia, Y. E., Scully, K. J., and Rosenberg, L. E.: Defective propionate carboxylation in ketotic hyperglycinemia. Lancet, $i: 757$ (1969).

11. Hsia, Y. E., and Scully, K. J.: Propionic acidemia: Diagnosed by enzyme assay in frozen leukocytes. J. Pediat. 83: 625 (1973).

12. Krieger, I., and Hart, Z.: Valine-sensitive nonketotic hyperglycinemia. J. Pediat., 85: 43 (1974).

13. Krieger, 1.: Growth failure and congenital heart disease. Amer. J. Dis. Child., 120: 497 (1970).

14. Levy, H. L., Erickson, A. M., Lott, L., and Kurtz, D. J.: Isovaleric acidemia: Results of family study and dietary treatment. Pediatrics, 52: 83 (1973).

15. Newman, C. G. H., Wilson, B. D. R., Cailaghan, P., and Young, L.: Neonatal death associated with isovaleric acidemia. Lancet, ii: 239 (1967).

16. Rasmussen, K., Ando, T., Nyhan, W. L., Hull, D., Cottom, D., Donnell, W.. Wadington, W., and Kilroy, A. W.: Excretion of propionylglycine in propionic acidemia. Clin. Sci., 42: 665 (1972).

17. Rosenberg, L. E., Lilljeqvist, A. C., and Hsia, Y. E.: Methylmalonic aciduria: An inborn error leading to metabolic acidosis, long chain ketonuria and intermittent hyperglycinemia. N. Engl. J. Med, 278: 1319 (1968).

18. Schachter, D., and Taggart, J. V.: Glycine $N$-acylase: Purification and properties. J. Biol. Chem., 208: 263 (1954).

19. Simila, S., and Visakorpi, J. K.: Clinical findings in three patients with non-ketotic hyperglycinemia. Ann. Clin. Res., 2: 151 (1970).

20. Stein, W. H., Paladini, A. C., Thirs, C. H. W., and Moore, S.: Phenylacetyl glutamines as a constituent of normal human urine. J. Amer. Chem. Soc., 76: 2848 (1954).

21. Tada, K., Yoshida, A., and Arakawa, T.: Free amino acid pattern in the liver from patients with amino acid diseases. Tohoku J. Exp. Med., 101: 223 (1970).

22. Tanaka, K.: Isovaleric acidemia and its induction in experimental animals by hypoglycin A. In: F. A. Hommes and C. J. van den Berg: Inborn Errors of Metabolism, p. 269 (Academic Press, New York, 1973).

23. Tanaka, K., and Isselbacher, K. J.: The isolation and identification of $\mathrm{N}$ isovalerylglycine from urine of patients with isovaleric acidemia. J. Biol. Chem., 242: 2966 (1967).

24. Tanaka, K., Budd, M. A., Efron, M. L., and Isselbacher, K. J.: Isovaleric acidemia: A new genetic defect of leucine metabolism. Proc. Nat. Acad. Sci., 56: 236 (1966).

25. Dr. Y. E. Hsia, from the Department of Human Genetics, Yale University, did the determination of leukocyte propionyl-CoA carboxylase. His contribution is gratefully acknowledged.

26. This investigation was supported by National Institutes of Health Grant no. AM 17453 and National Foundation Grant no. 1-378.

27. Requests for reprints should be addressed to: I. Krieger, M.D., Wayne State University School of Medicine, Children's Hospital of Michigan, 3901 Beaubien Blvd., Detroit, Mich. 48201 (USA).

28. Accepted for publication August 15, 1975. 